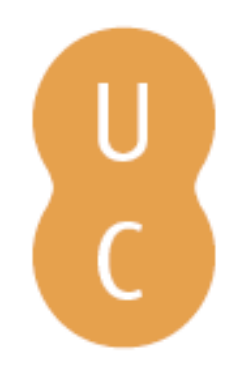

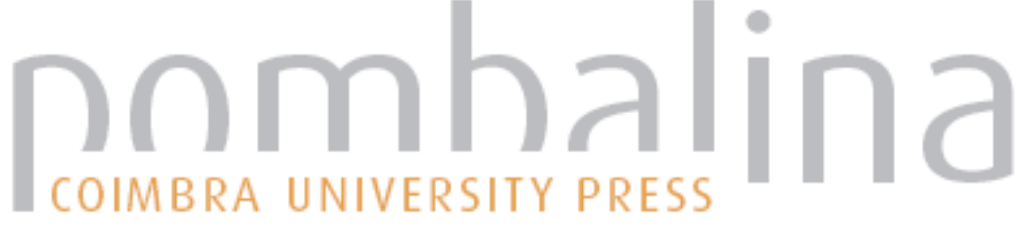

\section{Mixture detection applying mitochondrial DNA SNPS Vs aditional mitochondrial DNA sequencing}

\begin{tabular}{ll} 
Autor(es): & $\begin{array}{l}\text { Bento, A. M.; Costa, H. Afonso; Balsa, F.; Serra, A.; Lopes, V.; Andrade, } \\
\text { L.; Batista, L.; Oliveira, C.; Anjos, M. J.; Carvalho, M.; Corte-Real, F. }\end{array}$ \\
$\begin{array}{ll}\text { Publicado por: } & \text { Imprensa da Universidade de Coimbra; International Academy of Legal } \\
\text { Medicine }\end{array}$ \\
$\begin{array}{ll}\text { URL } \\
\text { persistente: }\end{array}$ & URI:http://hdl.handle.net/10316.2/31729 \\
DOI: & DOI:http://dx.doi.org/10.14195/978-989-26-0173-1_11 \\
Accessed : & 26-Apr-2023 10:42:52 \\
\hline
\end{tabular}

A navegação consulta e descarregamento dos títulos inseridos nas Bibliotecas Digitais UC Digitalis, UC Pombalina e UC Impactum, pressupõem a aceitação plena e sem reservas dos Termos e Condições de Uso destas Bibliotecas Digitais, disponíveis em https://digitalis.uc.pt/pt-pt/termos.

Conforme exposto nos referidos Termos e Condições de Uso, o descarregamento de títulos de acesso restrito requer uma licença válida de autorização devendo o utilizador aceder ao(s) documento(s) a partir de um endereço de IP da instituição detentora da supramencionada licença.

Ao utilizador é apenas permitido o descarregamento para uso pessoal, pelo que o emprego do(s) título(s) descarregado(s) para outro fim, designadamente comercial, carece de autorização do respetivo autor ou editor da obra.

Na medida em que todas as obras da UC Digitalis se encontram protegidas pelo Código do Direito de Autor e Direitos Conexos e demais legislação aplicável, toda a cópia, parcial ou total, deste documento, nos casos em que é legalmente admitida, deverá conter ou fazer-se acompanhar por este aviso.

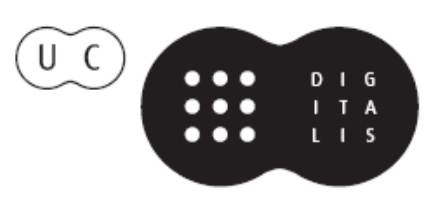




\section{Duarte Nuno Vieira Anthony Busuttil \\ Denis Cusack • Philip Beth}
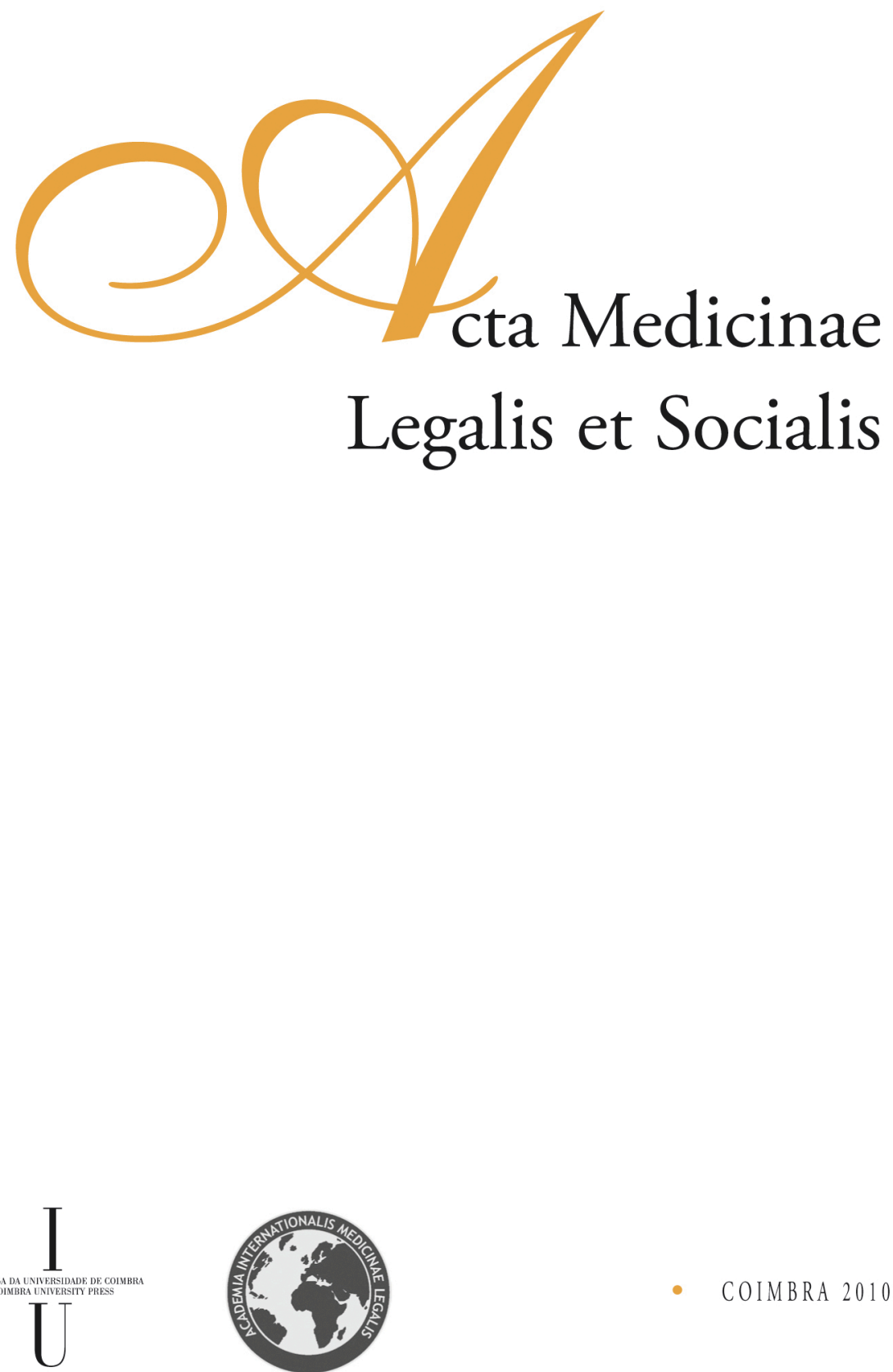
A. M. Bento ${ }^{1}$, H. Afonso Costa ${ }^{1}$, F. Balsa ${ }^{1}$, A. Serra ${ }^{1}$, V. Lopes ${ }^{1}$, L. Andrade ${ }^{1}$, C. Oliveira ${ }^{1}$, L. Batista ${ }^{1}$, M. J. Anjos ${ }^{1}$, M. Carvalho ${ }^{1}$, F. Corte-Real ${ }^{2,3}$

${ }^{1}$ Forensic Genetics Service, Centre Branch of the National Institute of Legal Medicine, Coimbra, Portugal

2 National Institute of Legal Medicine, Coimbra, Portugal

${ }^{3}$ Faculty of Medicine, University of Coimbra, Portugal

\title{
MIXTURE DETECTION APPLYING MITOCHONDRIAL DNA SNPS VS TRADITIONAL MITOCHONDRIAL DNA SEQUENCING
}

\begin{abstract}
Mitochondrial DNA (mtDNA) analysis found an important role in forensic genetics, especially when nuclear DNA analysis does not give a conclusive response. In this study, mitochondrial DNA Single Nucleotide Polymorphisms (mtSNP) analysis was compared to traditional mtDNA sequencing in order to determine the most useful method for mix detection, a reality in forensic genetics routine. MtSNP analysis allowed to detect mixtures in samples sharing the same haplotype for HV1/HV2 regions.
\end{abstract}

\section{Introduction}

Mitochondrial DNA (mtDNA) analysis found an important role in forensic genetics, especially when nuclear DNA analysis does not give a conclusive response. One major advantage of mtDNA in forensic casework is the high copy number of mtDNA molecules within the cell contrary to nuclear DNA, and its resistance in highly degraded samples, allowing analysis of low level DNA evidence. A major problem in mixture detection through mtDNA sequencing is to distinguish between basal noise and minor components of a mix. By the other hand, mtDNA hypervariable regions typing shows a low power of discrimination, specially when common haplotypes are present. In such cases, mtDNA coding region SNP analysis can be useful in combination with $\mathrm{HV} 1 / \mathrm{HV} 2$ analysis, to increase discrimination among individuals (1). In this study, mitochondrial DNA Single Nucleotide Polymorphisms (mtSNP) analysis was compared to traditional mtDNA sequencing in order to determine the most useful method for mix detection, a reality in forensic genetics routine.

\section{Material and Methods}

\section{DNA extraction and quantification}

DNA was extracted from blood samples using Chelex 100 protocol (2). DNA quantification was achieved with Quantifiler Human DNA Quantification Kit at an ABI Prism7000 Sequence Detection System (AB). 


\section{Mitochondrial sequencing}

Two blood mixtures were prepared and analysed for mtDNA HV1 and HV2 regions. PCR amplification was made according to Wilson et al, 1995 (3) and segments sequenced using BigDye Terminator v1.1 Cycle Sequence Kit (AB) with BetterBuffer (MicroZone Limited), followed by a simple bead purification method (XTerminator) to remove unincorporated terminators. Electrophoresis was achieved in an ABI PRISM 3130 Genetic Analyser (AB) and analysis was done with ABI DNA Sequencing Analysis v5.2 and SeqScape v2.5.

\section{MtSNPs}

To test the ability to detect mixtures using mtSNPs, a set of five different mixtures in different ratios (9:1 to 1:1) were prepared using DNA control 9947A and 9948 (both Promega) as well as the blood mixtures previously described.

Sixteen mtSNP were amplified in two multiplex reactions using primers proposed by Brandstätter et al, 2003 (4) and amplification protocol published by Parson et al, 2008 (5). Previous to minisequencing reaction, PCR products were treated with ExoSAP-IT (USB) in order to remove unincorporated dNTPs and excess of primers. $5 \mu \mathrm{l}$ of PCR product were incubated with $2 \mu \mathrm{l}$ of ExoSAP-IT for 90 minutes at $37^{\circ} \mathrm{C}$ followed by 20 minutes at $80^{\circ} \mathrm{C}$ for enzyme inactivation. Minisequencing reaction was achieved using SNaPshot kit (AB) according to Brandstätter et al, 2003 (4). Unincorporated ddNTPs were removed with a treatment with SAP (Roche Diagnostics Corporation). The minisequencing product was diluted 1:10 and the electrophoresis was undertaken on an ABI PRISM 3130 Genetic Analyzer using Liz-120 as size standard. Analysis was completed using GeneMapper ID v.3.2 software.

\section{Results}

In one blood mixture, HV1/HV2 analysis showed two bases at a large number of positions, indicating the presence of mixed samples and mtDNA SNP analysis confirmed the result (Figures 1 and 2).

For the other mixture, HV1 was CRS and HV2 analysis presented the 263G; 315.1C haplotype and no mixture was detected. Using mtSNP for the same samples, the mixture was detected, proofing the utility of this technology in forensic genetics since the observed HV1/HV2 haplotype is one of the most frequent in European populations. Although the samples shared the same haplotype, they belonged to different branches of haplogroup $\mathrm{H}$, namely $\mathrm{H} 1$ and $\mathrm{H} 3$, since the mixture was only detected in positions 3010 (Mx 1) and 6776 (Mx 2) (Figure 3).

MtSNP analysis of the five mixture sets (9:1 to 1:1) using DNA controls 9947A and 9948, allowed full mixture detection in all ratios, as seen in Figure 4. In a 6:4 mixture, the mix positions are well detected and quite balanced, whereas in a 9:1 mix peaks appeared, as expected, extremely unbalanced but evident. 


\section{Discussion and Conclusion}

In degraded samples without nuclear DNA, mtSNP analysis may allow mix detection even when HV1/HV2 haplotypes are identical. Comparing with traditional mtDNA sequencing, mtSNP analysis with $\mathrm{SNaPshot} \mathrm{technique} \mathrm{presents} \mathrm{a} \mathrm{major}$ advantage: each allele of a determined marker presents a slight deviation from one another. This deviation is due to mobility differences that occur depending on the incorporated terminator, which allows to better distinguish between basal noise and a minor component of a mixture.

Even in very unbalanced mixtures (9:1) it was possible to detect all SNPs in the studied mix ratios, showing the potentialities of this technique in forensics genetics.

\section{References:}

(1) COBlE, M.; JUST, R.; O'CALLAGHAM, J.; LETMANYI, I.; PETERSON, C.; IRWIN, J., PARSONS, T. Single nucleotide polymorphisms over the entire mtDNA genome that increase the power of forensic testing in Caucasians. Int. J. Legal Med. 118,137-146, 2004.

(2) WALSH, P.S., METZGER, D.A. \& HIGUCHI, R. Chelex 100 as a medium for simple extraction of DNA for PCR-based typing from forensic material. BioTechniques, 10, 506-513, 1991.

(3) Wilson, M.R., DiZINNO J. A., POLANSKEY D.,REPLOGLE J., BUDOWLE B. Validation of mitochondrial DNA sequencing for forensic casework. Int. J. Legal Med. 108, 68-74, 1995.

(4) BRANDSTÄTTER, A.; PARSONS, T., PARSON, W. Rapid Screening of mtDNA coding region SNPs for the identification of west European Caucasian haplogroups. Int. J. Legal Med. 117, 291-298, 2003.

(5) PARSON, W.; FENDT, L.; BALLARD, D.; BØRSTING, C.; BRINKMANN, B.; BUTLER, J.; CARRACEDO, A.; CARVALHO, M.; COBLE, M.D.; CORTE REAL, F.; DESMYTER, S.; DUPUY, B.M.; HARRISON, C.; HOHOFF, C.; HOSTE, B.; JUST, R.; KRÄMER, T.; MØRLING, N.; SALAS, A.; SCHMITTER, H.; SCHNEIDER, P.M.; VALONE, P., BRANDSTÄTTER, A. Identification of west Eurasian mitochondrial haplogroups by mtDNA SNP screening: Results of the 2006-2007 collaborative exercise. (2008) For Sci Int: Genetics, 2, 61-68, 2008. 


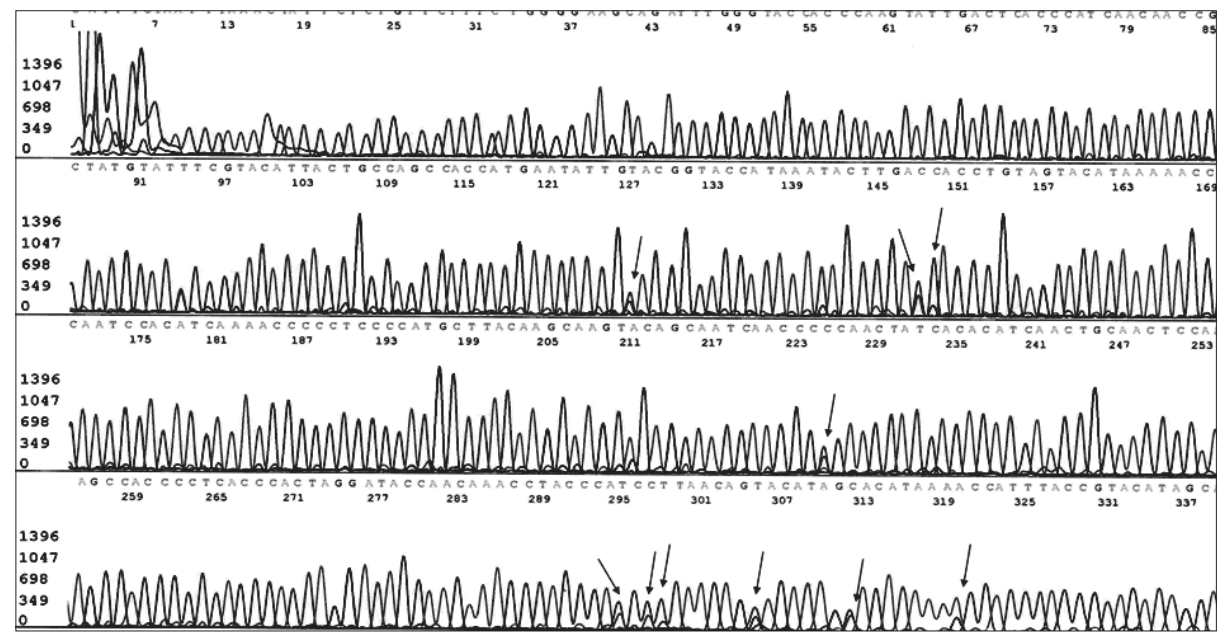

Figure 1 - Electropherogram of mitochondrial DNA sequencing using BigDye v1.1 from a blood mixture. The mixture is detected in several positions, signed with arrows.

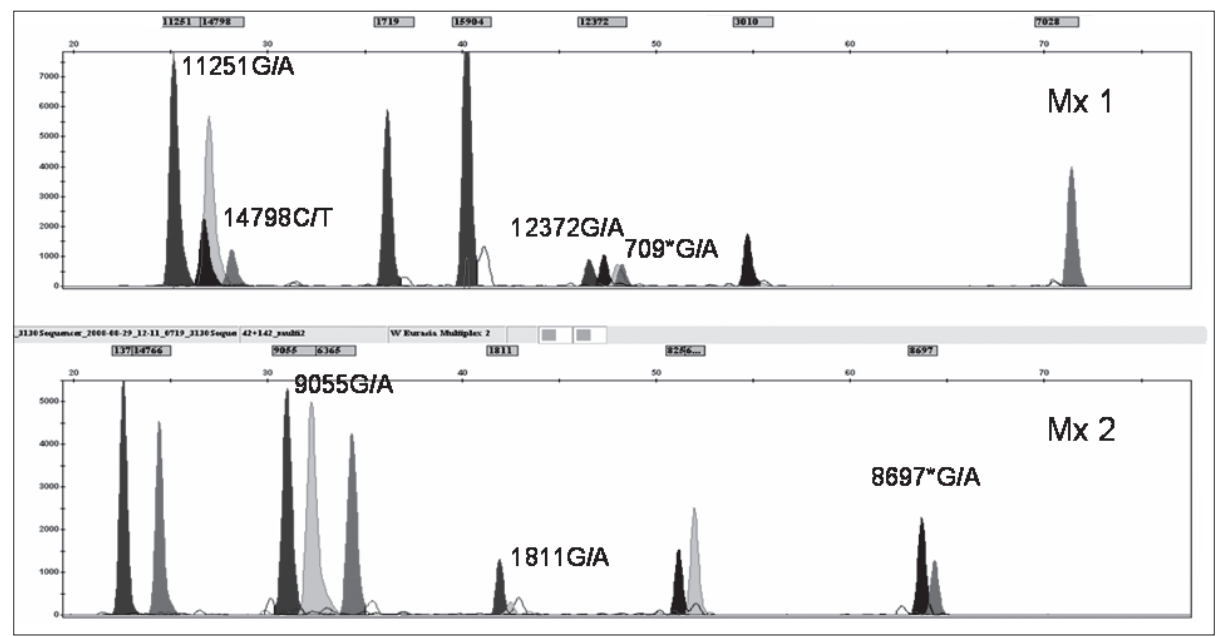

Figure 2 - Electropherograms of mtSNPs for multiplex 1 and 2 from a blood mixture. The mixture is detected in several markers. In the positions marked with * the true allele is the reverse of the detected one. 


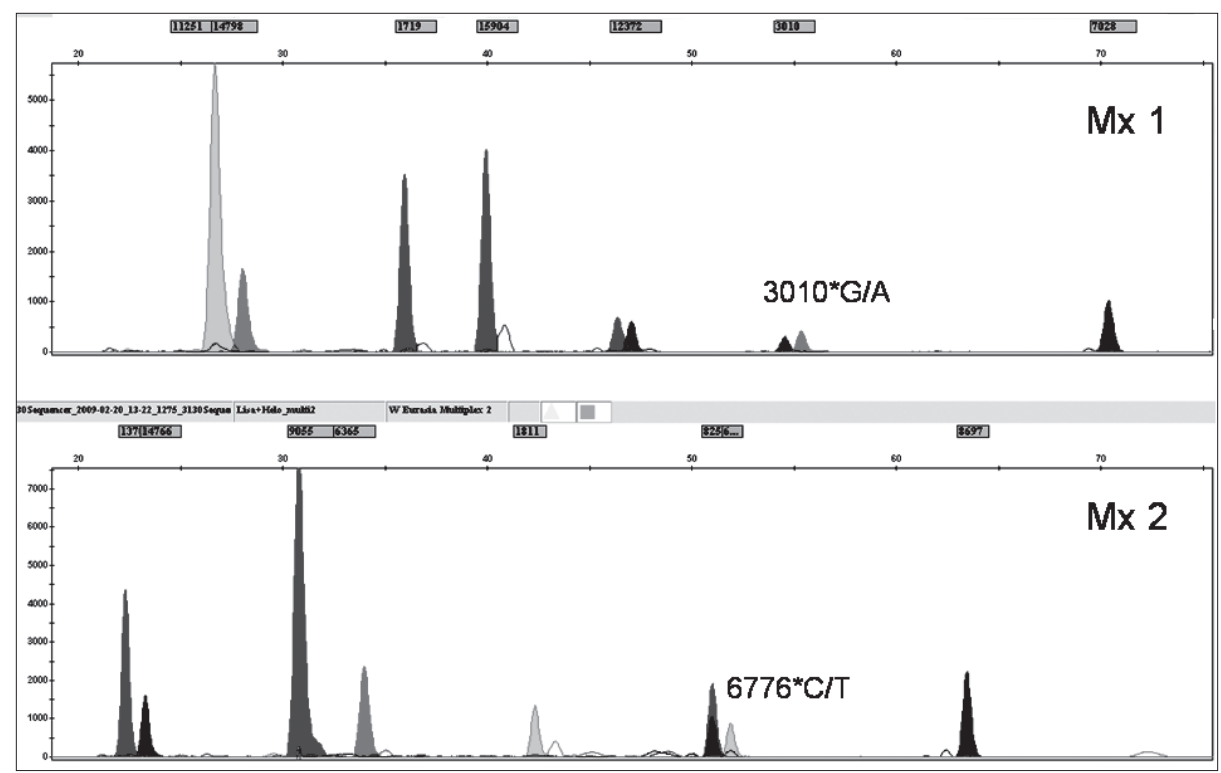

Figure 3 - Electropherograms of mtSNPs for multiplex 1 and 2 from a blood mixture. The mixture is detected in only two markers as both samples belong to haplogroup H (H1 and H3). In the positions marked with * the true allele is the reverse of the detected one.

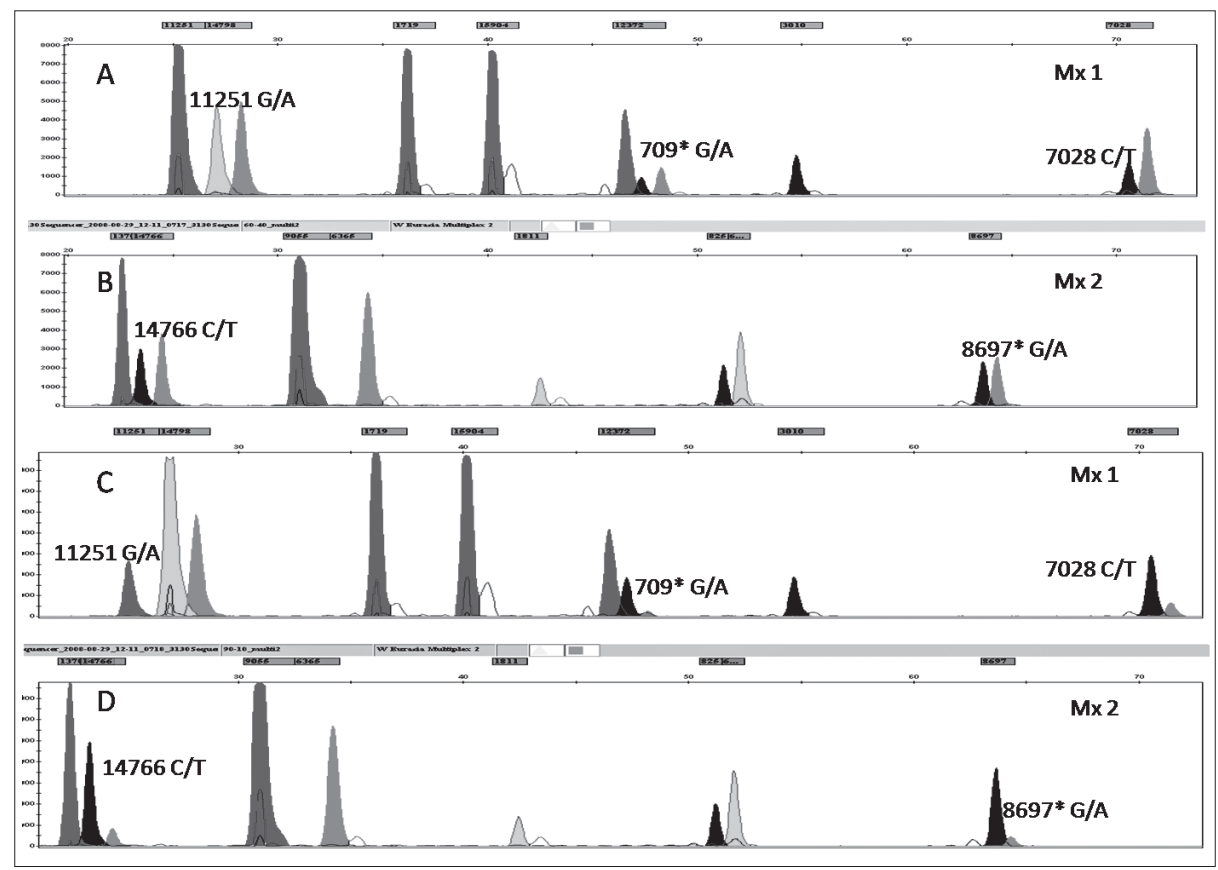

Figure 4 - Electropherograms of mtSNPs for multiplex 1 and 2 from mixture using DNA controls 9947A and 9948. A: multiplex 1 for a 6:4 mix; B: multiplex 2 for a 6:4 mix; C: multiplex 1 for a 9:1 mix; D: multiplex 2 for a 9:1 mix. The mixture is detected in several markers, as indicated by the positions. In the positions marked with ${ }^{*}$ the true allele is the reverse of the detected one. 